\title{
Global Response in Skin
}

National Cancer Institute

\section{Source}

National Cancer Institute. Global Response in Skin. NCI Thesaurus. Code C159951.

Criteria for the response to treatment in skin lesions, as a component of global response. 